\author{
AmELIA KRAWCZYK-BOCIAN \\ Uniwersytet Kazimierza Wielkiego \\ $w$ Bydgoszczy
}

\title{
ROZUMIENIE NARRACYJNE W PERSPEKTYWIE INTERAKCJONIZMU INTERPRETATYWNEGO, POZNANIA HERMENEUTYCZNEGO I REFLEKSJI FENOMENOLOGICZNEJ
}

\begin{abstract}
AвSTRACT. Krawczyk-Bocian Amelia, Rozumienie narracyjne w perspektywie interakcjonizmu interpretatywnego, poznania hermeneutycznego i refleksji fenomenologicznej [The Narrative Understanding in the Aspect of Interpretative Interactionism, Hermeneutic Knowledge and Phenomenological Reflection]. Studia Edukacyjne nr 44, 2017, Poznań 2017, pp. 285-300. Adam Mickiewicz University Press. ISSN 1233-6688. DOI: $10.14746 /$ se.2017.44.17

The conceptual category of the reasoning narrative is the starting point for the considerations presented. Looking at the concept through the prism of interpretative interactionism and the phenomenological and hermeneutic approach helps to discover the meaning and significance of each of the perspectives for the discovery of wealth of understanding of everything that the human person is involved in and of the world he resides in, creates and converts to his own needs. The considerations in the text stress the importance of human reflection, ability to retrace feelings in the individual biography and of being able to interpret one's own experiences. Presenting these considerations in the biographic-narrative orientation reveals the essence of understanding of the issues discussed in the article from the perspective of the experiencing subject.
\end{abstract}

Key words: understanding, interactionism, hermeneutics, phenomenology, biographical-narrative research

\section{Wprowadzenie}

Niniejszy tekst stanowi próbę odczytania kategorii pojęciowej rozumienie narracyjne $\mathrm{w}$ perspektywie hermeneutyczno-fenomenologicznej oraz interakcjonizmu interpretatywnego. Odwołując się do własnych doświadczeń badawczych, polegających na stosowaniu powyższych perspektyw, 
w warsztacie metodologicznym ukazuje ważność pojęcia „rozumienia” na wszystkich etapach pracy badawczej. Zastosowanie analizowanych perspektyw $\mathrm{w}$ procesie badawczym może stać się punktem wyjścia odkrycia płaszczyzny rozumienia jako osobliwego spotkania badacza z badanym. Owe spotkanie przybiera postać dyskursu, współbycia, współodczuwania w świecie znaczeń nadawanych własnemu doświadczeniu przez pryzmat orientacji czasu.

Podkreślam, iż zawarte $\mathrm{w}$ tekście rozważania stanowią moje indywidualne odczytanie istoty kategorii narracyjnego rozumienia $\mathrm{w}$ procesie badawczym. Jako badacz jakościowy, poszukujący i nieustanie zgłębiający warsztat badawczy, stawiam sobie nurtujące pytania. Nie na wszystkie udzielam odpowiedzi. Podchodzę do nich jak do "otwieraczy” nowych drzwi, z możliwością spojrzenia na nie z punktu widzenia nowych perspektyw rozumienia tego, w czym uczestniczymy.

\section{Rozumienie narracyjne}

Co to znaczy rozumieć narracyjnie? Próba odpowiedzi na to pytanie wcale nie będzie łatwa. Stąd, w moim przekonaniu, rozpocznę swoje rozważania od postawienia tezy: Świat człowieka jest światem jego osobistej narracji, która polega na ustawicznym wczytywaniu się w przeżycia i doświadczenia stające się jego udziałem oraz losu, z którym się zmierza.

Takie spojrzenie na proces rozumienia własnego życia z perspektywy biograficznej - narracyjnej odsłania trzy niezwykle istotne elementy. Pierwszy ukazuje obraz siebie, to jest podmiotu, który w perspektywie czasu dokonuje oglądu ważnych z jego punktu widzenia zmian (przemian) we własnej biografii. Ta próba odpowiedzi na fundamentalne pytania stawia człowieka przed koniecznością zatrzymania się choć na chwilę w biegu własnego życia. Pytam zatem: kim jestem? co tworzę swoim działaniem? jaki mam potencjał wewnętrzny, który różni mnie od innych ludzi? jak mogę go wykorzystać, aby życie które tworzę przepełnione było satysfakcją, zostało pozytywnie ukierunkowane? Jak zrozumieć obszar swoich działań, w którą stronę go pokierować? Te i inne pytania kierują człowieka do drugiego obszaru jego istnienia, mianowicie obszaru zdarzeń, w których jako podmiot uczestniczy - zdarzeń, które na stałe wpisują się w jego narracyjną biografię. To obszar niezwykle istotny z punktu widzenia uczestnictwa w życiu społecznym, rodzinnym, zawodowym.

Proces rozumienia tego wszystkiego, co staje się udziałem człowieka wpisanego w zdarzenia (często krytyczne, dramatyczne) w jego biografii prowa- 
dzi do porządkowania historii życia, nadawania mu sensu i znaczenia z perspektywy czasu. Rozważania te wiążą się niewątpliwie z ostatnim obszarem - wpisującym się, $\mathrm{w}$ moim przekonaniu, $\mathrm{w}$ proces rozumienia narracyjnego życia. Jest nim obszar zmian/ przemian biograficznych. Ta niezwykła faza refleksji polega na chwili wyciszenia, zadumy nad tym wszystkim, co biograficznie się przydarzyło.

Powyższe elementy wpisują się $\mathrm{w}$ propozycję Jerzego Trzebińskiego ${ }^{1}$ rozumienia struktury narracji, do której autor zalicza głównego bohatera (narratora), trudności, z którymi się styka, z którymi w biografii się zmaga oraz proces przezwyciężania owych trudności w procesie biograficznego czasu.

Biorąc pod uwage powyższe stwierdzenia, możemy zatem przyjąć, iż rozumienie narracyjne zakłada posiadanie tzw. kompetencji biograficznej. Zdaniem Zbigniewa Pietrasińskiego², chodzi o umiejętność jednostki konstruowania własnej historii życia, porządkowania jej znaczących obszarów, określania siebie, swojego miejsca w świecie na drodze indywidualnego rozwoju. W takiej sytuacji dochodzi do głosu wewnętrzne przekonanie o ważności biograficznych procesów nastawionych na rozwój - integrację wewnętrzną, rozwój wewnętrznego potencjału tkwiącego w każdym człowieku pozytywnie nastawionego do życia, do zmian, przekształcania (również na swoje potrzeby) najbliższego środowiska.

Zdaniem Paula Ricoeura ${ }^{3}$, w rozumieniu narracyjnym chodzi przede wszystkim o spojrzenie na siebie i własny świat z pewnego dystansu. Daje to gwarancję wyciszenia emocji, zdystansowania się od problemów, zawiłości zewnętrznego świata, w którym jako podmioty uczestniczymy. Poza tym, jednostka uzyskuje zdolność ponownego poznania (rozpoznania) siebie. To bogactwo nowej wiedzy o sobie samym pozwala odkrywać nowe obszary działalności człowieka, prowadzi do nadania życiu nowego sensu i znaczenia w biograficznej przestrzeni.

Powyższe rozważania kierują zatem do sformułowania kilku pytań: W jaki sposób narracyjne (z)rozumienie pozwala:

1) nazywać, odkrywać siebie w perspektywie czasu?

2) porządkować ważne biograficzne zdarzenia?

3) odkrywać nowe, nieznane dotąd jednostce obszary działalności?

${ }^{1}$ J. Trzebiński, Narracja jako sposób rozumienia świata, Gdańsk 2002, s. 22.

2 Z. Pietrasiński, Syntezy wiedzy autobiograficznej podporzadkowane "roli" autokreacyjnej jednostki, [w:] O biografii i metodzie biograficznej, red. T. Rzepa, J. Leoński, Poznań 1993, s. 63; por. K. Stemplewska-Żakowicz, B. Zalewski, Czym jest dobra narracja? Struktura narracji z perspektywy badacza i klinicystów, [w:] Badania narracyjne w psychologii, red. M. Śtraś-Romanowska, B. Bartosz, M. Żurko, Warszawa 2010, s. 17-51.

${ }^{3}$ P. Ricoeur, Jezzyk, tekst, interpretacja. Wybór pism, Warszawa 1989, s. 244. 
Te i inne pytania kierują moją uwagę ku procesowi urzeczywistniania siebie $\mathrm{w}$ roli aktywnego podmiotu, któremu jest dane doświadczać siebie w warunkach zmian osobistych, społecznych, zawodowych, czy rodzinnych. Jakkolwiek by nie spojrzeć na proces rozumienia, widoczna jest zmiana, która nabiera znaczenia dopiero w perspektywie czasu. Jak rzekłaby Charles Taylor: „narracyjne rozumienie życia, świadomość tego, kim się stałem może być uzyskane tylko w narracji" ${ }^{4}$.

Rozumiemy zatem siebie rozmawiając ze sobą w codzienności. Próbujemy rozumieć innego człowieka wówczas, kiedy godząc się na osobliwe spotykanie śledzimy uważnie to, co chce nam przekazać. Te oczywiste często spotkania ukazują wolę bycia $\mathrm{z}$ innym $\mathrm{w}$ przestrzeni dialogu, bycia razem $\mathrm{w}$ procesie komunikacji ujawniającym się w naszej ludzkiej zdolności do snucia opowieści. Może, ale wcale nie musi być to spotkanie badawcze. Ujawniamy wolę rozumienia swojego wewnętrznego świata przy każdej nadarzającej się okazji, która prowadzi do procesu nadawania sensów i znaczeń przeżyciom i doświadczeniom w biegu życia. Stąd, rozumienie siebie wyrażone $\mathrm{w}$ narracji traktuje jako punkt wyjścia tworzenia, przekształcania, czy też dookreślania tożsamości człowieka. Jest to niewątpliwie długi proces poznawania siebie $\mathrm{w}$ warunkach zmian, przemian biograficznych.

Powracając do postawionej na wstępie tezy, dochodzę do wniosku, iż rozumienie narracyjne sprzyja rekonstrukcji życia, wyzwala zdolność nazywania, porządkowania wydarzeń w biografii osobistej, pozwala dookreślać stale dojrzewającą tożsamość człowieka. Na koniec prowadzi do samowiedzy, samoświadomości, autorefleksji, elementów, które stają się niezbędne dla prawidłowego funkcjonowania człowieka. (Z)rozumienie tego, co mówi mi mój wewnętrzny świat staje się punktem wyjścia do zmian w postrzeganiu siebie, swojego działania, kontaktów interpersonalnych z innymi ludźmi.

Powyższą próbę odczytania procesu narracyjnego (z)rozumienia pragnę odnieść do trzech perspektyw, w których istota doświadczania, przeżywania, a w zasadzie rozumienia jest szczególnie widoczna i zarazem znacząca. Mowa o interakcjonizmie interpretatywnym, hermeneutyce i fenomenologii. Stosując zarówno interakcjonizm interpretatywny ${ }^{5}$, jak i heremeneutykę ${ }^{6}$ $\mathrm{w}$ procesie badawczym określam ich znaczenie i sens dla odkrywania oraz wydobywania ważnych z punktu widzenia badań danych.

Rozczytanie owych perspektyw staje się przedmiotem opisu w dalszej części artykułu.

\footnotetext{
${ }^{4}$ Ch. Taylor, Sources of the Self. The Making of the Modern Identity, Cambridge 1989, s. 34.

5 A. Krawczyk-Bocian, Doświadczanie zdarzeń krytycznych. Narracje biograficzne dorostych dzieci alkoholików, Bydgoszcz 2013.

${ }^{6}$ A. Krawczyk-Bocian, Biograficzne doświadczanie (nie)petnosprawności. W świetle teorii dezintegracji pozytywnej Kazimierza Dąbrowskiego" (w przygotowaniu).
} 


\section{Interakcjonizm interpretatywny jako centralna struktura znaczeniowa w biografii człowieka}

Powstanie interakcjonizmu sytuuje się na ostatnie dziesięciolecie XIX wieku oraz pierwszą dekadę XX wieku. Szczególne miejsce zajmuje tutaj obecność podmiotu, który za pomocą języka wyraża osobiste doświadczenia, biograficzne przeżycia. Język przekazu traktowany jest zatem tutaj jako „okno umożliwiające wgląd w wewnętrzne życie jednostki"7.

Mówiąc o interakcjonizmie interpretatywnym warto odwołać się do jego przedstawiciela, którym niewątpliwie jest Norman Denzin. Twierdzi on, iż przedmiotem interakcjonizmu jest doświadczenie człowieka, przeżyte doświadczenie w biografii indywidualnej pojedynczego człowieka oraz sens nadawany temu doświadczeniu w perspektywie czasu. Czy oznacza to zatem, że w trakcie biegu swojego życia jednostka dokonuje próby oglądu, oceny tego, co jej się biograficznie przydarzyło? Czy nadaje sensy i znaczenia biografii indywidualnej poprzez pryzmat trudnych, determinujących doświadczeń życiowych, które wymuszają na niej niejako zmianę swojego dotychczasowego funkcjonowania w różnych obszarach życia? Otóż, zdaniem Normana K. Denzina ${ }^{8}$, „przeżyte doświadczenie ogarnia podmiot sytuując go w polu interakcyjnym, które wiąże jednostkę z innymi”. Przyglądając się powyższemu stwierdzeniu możemy dojść do wniosku, iż na terenie pola interakcyjnego, o którym wspomina autor, dochodzi do wymiany kontaktów interpersonalnych. To one decydują zapewne o tym, w jaki sposób jednostka jest w stanie ogarnąć przeżyte doświadczenie, nadać mu sens i rozumienie z perspektywy czasu. Jak dalej stwierdza Denzin ${ }^{9}$, „przeżyte doświadczenie, wspólne dwóm lub więcej uczestnikom, jest procesem czasowym, emocjonalnym i poznawczym, polegającym na jednoczesnej penetracji przeszłości, teraźniejszości i przyszłości w pojedynczym fragmencie interakcji”. Pojawiająca się w tym miejscu kategoria pojęciowa czasu nabiera szczególnego znaczenia. Skoro przeszłość teraźniejszość i antycypowana przyszłość odgrywają tak znaczącą rolę w procesie narracyjnego rozumienia tego co się wydarzyło, to muszą odbywać się na polu interakcji z innymi ludźmi. Możemy zadać sobie zatem pytanie: w jaki sposób udział innych ludzi w naszym życiu sprawia, iż stają się oni osobami znaczącymi biograficznie? W jaki sposób obecność innych ludzi przyczynia się do procesu rozumienia tego, co się w życiu wydarzyło? Są to pytania niezwykle istotne. Odpowiedzi na nie szukamy in-

${ }^{7}$ I. Kawecki, Wiedza praktyczna nauczyciela, Kraków 2004, s. 91.

${ }^{8}$ N.K. Denzin, Reinterpretacja metody biograficznej w socjologii: znaczenie a metoda $w$ analizie biograficznej, [w:] Metoda biograficzna w socjologii, red. J. Włodarek, M. Ziółkowski, Warszawa 1990, s. 56.

${ }^{9}$ Tamże, s. 56. 
dywidualnie. Rozglądamy się wokól, spoglądamy na ludzi, z którymi przebywamy w codzienności. Samodzielnie stawiamy nowe pytania, samodzielnie szukamy na nie odpowiedzi.

Patrząc na powyższe rozważania z punktu widzenia interakcjonizmu interpretatywnego, możemy w tym miejscu przywołać słowa Normana Denzina, który twierdzi, iż

organizm ludzki nie jest biernym odbiorcą oddziałujących nań bodźców, lecz aktywnie reaguje na sytuacje, w obliczu których staje. Z tego względu zachowanie jednostki musi być postrzegane jako stała adaptacja do środowiska, dokonująca się w sposób ciągły, i w toku której permanentnie zmienny organizm podejmuje uporządkowane działania o charakterze sekwencyjnym, gdzie wyraźnie jest zaznaczony początek, środek i koniec ${ }^{10}$.

To aktywne reagowanie na sytuację, w obliczu której staje człowiek w swojej codzienności, to zapewne wyzwania, ukierunkowanie zadania, które powodują, iż podejmuje on w najbliższym swoim otoczeniu działania, aby zmienić aktualną sytuację życiową. Oczywiście, dokonuje się to w polu interakcyjnym, przy współudziale, współpracy innych ludzi, ale i samej aktywnej jednostki, która przeżyte doświadczenia próbuje ogarnąć, uporządkować, nadać im sens i znaczenie w perspektywie czasu.

Norman Denzin ${ }^{11}$ mówiąc o interakcjonizmie interpretatywnym, podkreśla fakt, iż przeżytym doświadczeniom człowiek przypisuje znaczenia. Pierwsze z nich jest znaczeniem powierzchownym. Człowiek porządkuje je za pomocą czynności dnia codziennego. Zatem, wszystko co człowiekowi wydarza się w przestrzeni codziennej, próbuje dostępnymi mu strategiami zaradczymi wyjaśnić, zrozumieć, wykorzystując w tym celu dostępną mu wiedzę. Drugie znaczenie Denzin nazywa znaczeniem głębszym. Według niego jest to wyzwanie do

przyjęcia interpretatywnego punktu widzenia, który rozpatruje bogaty, rozbudowany wewnętrznie świat jaźni, uczuć i głębokich znaczeń. Interakcjonizm interpretatywny dostarcza opisów doświadczenia takiego, jakie jest przeżywane na owym wewnętrznym, głębokim poziomie znaczeniowym ${ }^{12}$.

W taki oto sposób, zdaniem autora, interakcjonizm interpretatywny dostarcza opisu doświadczenia takiego, jaki w danej chwili jest odczuwany, językowo nazywany, emocjonalnie wyrażony. Możemy zatem dojść do wniosku, iż punktem wyjścia interakcjonizmu interpretatywnego staje się odkrycie centralnej struktury znaczeniowej w biografii osoby badanej. Oznacza to, że

\footnotetext{
${ }^{10}$ I. Kawecki, Wiedza praktyczna nauczyciela, s. 93.

${ }^{11}$ N.K. Denzin, Reinterpretacja metody biograficznej w socjologii, s. 57.

${ }^{12}$ Tamże, s. 57.
} 
odkrycie owej struktury znaczeniowej nie jest możliwe bez odwołania się do refleksji, do procesu rozumienia swojego środowiska wewnętrznego oraz do empatii. Zatem, by pojąć zarówno swoją historię życia, jak i historię życia drugiej osoby, z którą jak twierdzi Denzin spotykamy się ustawicznie w polu interakcyjnym, trzeba spojrzeć na jej doświadczenia jej oczami, przeżyciami, procesem rozumienia.

Zdaniem Ireneusza Kaweckiego ${ }^{13}$, emocje i uczucia są podstawowymi elementami przekonań, które pozwalają nam opisywać doświadczenia w realnym życiu. Skoro zatem punktem wyjścia interakcjonizmu interpretatywnego uczyniono przeżyte doświadczenie, rozumienie tego doświadczenia, nadawanie mu sensu i znaczenia w perspektywie czasu, trzeba odwołać się do penetracji przeszłości, teraźniejszości i antycypowanej przyszłości w myśleniu indywidualnym. Ułatwi to zarówno badaczowi, jak i narratorowi, z którym spotykamy się $\mathrm{w}$ trakcie badań biograficzno-narracyjnych rozumienia tego wszystkiego, co staje się naszym udziałem. Oczywiście z towarzyszącym repertuarem emocji $\mathrm{w}$ tle.

Rozumieć narracyjnie w perspektywie interakcjonizmu interpretatywnego oznacza zatem spojrzeć na istotę narracji przez pryzmat komunikacji. Jak powiedziałby Walter Fisher ${ }^{14}$ - komunikacji zakorzenionej w czasie i przestrzeni. Obejmowałaby ona swym zasięgiem każdy aspekt ludzkiego życia, uwzględniałaby nasz charakter, motywy i działania. Autor kontynuując powyższy wątek dodaje, iż komunikat staje się narracją, gdyż zakorzeniony jest aktualnej historii rozmówcy. Ma zatem swój początek, rozwinięcie i zakończenie. Zaprasza odbiorców do własnej interpretacji, wysuwania wniosków, snucia refleksji, oceny, nadawania znaczenia i wartości zarówno dla narratora, jak i innych ludzi.

Reasumując, interakcjonizm interpretatywny mocno akcentuje odkrycie struktury znaczeniowej w biografii osoby badanej. Ta struktura znaczeniowa obejmuje zatem te obszary, które pozostawały poza zasięgiem interpretującego badacza. Tym interpretującym badaczem jest zarówno narrator, który sam pod wpływem snucia opowieści rekonstruuje to co mu się biograficznie przydarzyło, ale i sam badacz, który w istocie narracyjnego spotkania ma możliwość dotarcia do zakamarków wewnętrznego świata człowieka, ukazującego niezwykle bogatą historię swojego życia.

Okazuje się zatem, iż centralna struktura znaczeniowa w biografii osoby badanej obejmuje nie tylko doświadczenia, sensy i znaczenia, jakie jednostka nadaje temu co przeżyła, ale również emocje i uczucia, które powstały pod jej wpływem. Odkrycie ich zasięgu, mocy sprawczej pozwala dotrzeć do tych obszarów ludzkiej działalności, które do tej pory okryte były zmową milczenia.

\footnotetext{
${ }^{13}$ I. Kawecki, Wiedza praktyczna nauczyciela, s. 92.

${ }^{14}$ E. Griffin, Podstawy komunikacji społecznej, Gdańsk 2002, s. 327.
} 


\section{Rozumienie narracyjne w perspektywie hermeneutycznej}

Hermeneutyka jako „sztuka” interpretacji tekstów ${ }^{15}$ zwraca uwagę na proces rozumienia, objaśniania tekstów. Zdaniem Martina Heideggera, hermeneutyka opiera się na założeniu, iż cały ludzki byt jest niekończącym się procesem rozumienia, a język staje się narzędziem opisującym ludzkie doświadczenia ${ }^{16}$. Podobnie ujmuje tę perspektywę Dilthey. Sądzi on, iż rozumienie staje się bogatym $\mathrm{w}$ wiedzę procesem, $\mathrm{w}$ którym rozpoznajemy to co wewnątrz po znakach danych zewnętrznie i zmysłowo ${ }^{17}$.

To słowo wstępu dostarcza wiedzy o celach heremeneutyki, którym staje się rozumienie doświadczenia człowieka, próba jego opisu, wyjaśnienia, czy interpretacji. Jest to możliwe za pomocą tekstu, który udziela wiedzy o społecznym kontekście życia osoby, z którą wchodzimy w komunikację badawczą. Odkrywanie krok po kroku subiektywnej interpretacji doświadczenia człowieka prowadzi konsekwentnie do odkrywania znaczeń, jakie nadaje narrator w toku komunikacji. Stąd, zdaniem Teresy Bauman, punktem wyjścia poznania hermeneutycznego trzeba uczynić doświadczenie życia pojedynczego człowieka.

Rozumienie życia każdej osoby przebiega po kole (kole hermeneutycznym), żyjąc człowiek rejestruje określone przeżycia, które decydują o tym, jak interpretuje on swoje następne doświadczenia. Każdy fragment życia uzyskuje więc swoje znaczenie dopiero w kontekście całości, ale sam także wpływa na tę całość ${ }^{18}$.

Badacz decydując się na interpretację hermeneutyczną, bierze zatem pod uwagę znaczenie kategorii pojęciowej rozumienia. Tym samym, kategoria ta stanowi przedmiot badań hermeneutyki. Kluczową sprawą w perspektywie hermeneutycznej staje się zatem interpretacja. Badacz, aby dokonać interpretacji powinien stać się aktywnym słuchaczem. Wsłuchuje się zatem $\mathrm{w}$ tekst opowiadany mu przez człowieka. Śledzi wraz z nim momenty przełomowe, znaczące, krytyczne w jego biografii ${ }^{19}$. Swoiste wejście w przestrzeń mówio-

\footnotetext{
s. 142 .

${ }^{16}$ M. Nowak-Dziemianowicz, Edukacja i wychowanie w dyskursie nauki i codzienności, Kraków 2012, s. 31.

${ }^{17}$ K. Ablewicz, Hermeneutyczno-fenomenologiczna perspektywa badań w pedagogice, Kraków 1994, s. 29.

${ }^{18}$ T. Bauman, Poznawczy status danych jakościowych, [w:] Metodologiczne problemy tworzenia wiedzy w pedagogice. Oblicza akademickiej praktyki, red. J. Piekarski, D. Urbaniak-Zając, K. Szmidta, Kraków 2011, s. 273.

${ }^{19}$ Por. M. Nowak-Dziemianowicz, Edukacja i wychowanie w dyskursie nauki i codzienności, s. 32 .
}

${ }^{15}$ H. Krúger, Wprowadzenie w teorie i metody badawcze nauk o wychowaniu, Gdańsk 2005, 
nego tekstu poprzez interpretację hermeneutyczną stwarza okazję dotarcia do świata przeżyć i doświadczeń narratora. Ów tekst staje się punktem wyjścia do rozumienia człowieka, jego życia, momentów krytycznych w jego jednostkowej biografii. Jak mówi Paul Ricouer,

sens albo znaczenie narracji powstaje na przecięciu świata tekstu ze światem czytelnika. To akt czytania dopełnia pracę, przekształcając ją w przewodnik po czytaniu, wraz $\mathrm{z}$ jego sferami nieokreśloności, ukrytym bogactwem interpretacji i reinterpretacji ${ }^{20}$.

Dla badacza - hermeneuty istotne staje się zatem uchwycenie istoty opowiadanej historii. Świat opowiadany zostaje ukazany w formie tekstu, który dostarcza wiedzy o narratorze, jego historii życia, znaczeń i wartości jakie przypisuje ważnym biograficznie zdarzeniom. Celem staje się opisanie „osobliwego obszaru rzeczywistości, to jest indywidualnych, subiektywnych interpretacji świata" 21.

Cóż zatem znaczy odczytać biografie człowieka jako tekst? Anna Walczak twierdzi, że

rozumienie tekstu jest pochodną doświadczenia osobistego - relacji „Ja-ty”. „Ty” nie jest tu osobą, która bezpośrednio zadaje pytania i udziela odpowiedzi, ale właśnie tekstem. Tekst, jako właśnie jakieś „ty”, zwraca się do czytającego, stawia jakieś pytania i w ten sposób zaprasza do dialogu. Wysiłek rozumienia tego, co tekst mówi, polega przede wszystkim na wstępnym założeniu sensowności tekstu ${ }^{22}$.

Przyjmując powyższe stwierdzenie, należy podkreślić istotę rozumienia tego co badamy. Trudno zrozumieć zatem tekst, który nic nam nie mówi, trudno zrozumieć biografie człowieka, o którym nic nie wiemy. Spotkanie z biografią ujętą w formie tekstu zaprasza zatem do dialogu dwóch stron badacza i narratora.

Zrozumienie tego, co chce nam przekazać narrator nie jest zatem możliwe bez przyjęcia jego subiektywnej interpretacji świata przeżyć i doświadczeń. Zakładam zatem, iż ludzie uznają własne rozumienie świata, opisują go za pomocą swojego języka, własnych spostrzeżeń i refleksji. W związku z powyższym istotne staje się wsłuchanie w głos narratora, jak również w głos badacza. Refleksja interpretacyjna, w moim odczuciu niezbędna podczas prowadzenia badań, sprzyja stawianiu pytań dotyczących zarówno tego, co się dzieje z narratorem, ale i z badaczem - współtowarzyszem podróży po świe-

${ }^{20}$ P. Ricoeur, Interpretacja a refleksja: Konflikt hermeneutyczny, Studia Filozoficzne, 1986, 9, s. 26.

${ }^{21}$ M. Straś-Romanowska, Na tropach psychologii jako nauki humanistycznej, Warszawa - Wrocław 1995, s. 28.

${ }^{22}$ A. Walczak, Czego można się nauczyć z biografii innych? Przyktad Edith Piaf - istoty dramatycznej porwanej namiętnościa, [w:] Biografie i uczenie się, red. E. Dubas, J. Stelmaszczyk, Łódź 2015, s. 102. 
cie przeżyć i doświadczeń. W taki oto sposób stajemy się aktorami na scenie własnego życia. Jak twierdzi Monika Grochalska, „(re)konstruując swoją przeszłość, (re)konstruujemy także obraz siebie. To kim jesteśmy jest w dużej mierze kreowane przez autobiograficzne narracje" ${ }^{23}$.

Przystępując do interpretacji tekstu narracyjnego ${ }^{24}$, który staje się opisem obszaru życia człowieka, pytamy również, co dzieje się z nami. Jak zatem wewnętrznie radzimy sobie z emocjami, subiektywnymi odczuciami, w jaki sposób odnosimy to co słyszymy do własnej historii życia, własnych przeżyć i doświadczeń. Odpowiedzi na te pytania udziela nam Wilhelm Dilthey, twierdząc, iż jednostki są skazane na kontakt ze sobą. Muszą być zrozumiałe dla siebie nawzajem. "Jedna musi wiedzieć czego chce druga" ${ }^{25}$. Z tego też względu relacja pomiędzy osobami powinna być czytelna, jasna, niezafałszo-

${ }^{23}$ M. Grochalska, Transgresyjne trajektorie. Zmiany statusu społecznego w perspektywie biograficznej, Kraków 2011, s. 120.

${ }^{24}$ Problematykę interpretacji tekstu narracyjnego prezentuję szczegółowo w Przeglądzie Pedagogicznym nr 1/2008. W artykule omawiam następujące fazy. Faza pierwsza to przedrozumienie problemu, która dotyczy dotychczasowej wiedzy badacza o przedmiocie swojego poznania. Przedrozumienie wpisuje się zatem w koło hermeneutyczne i jest związane ze stawianiem pytań pobudzających badacza do refleksji, przełamywania stereotypów i schematów potocznego myślenia o badanym obiekcie/zjawisku. Faza druga nawiązuje do analizy dwubiegunowej relacji: obiekt badań - badacz, w której badacz odpowiada sobie na pytania: Kogo ja właściwie badam? Co wiem o jego życiu? Co szczególnie mnie interesuje? Te i inne pytania kierują uwagę badacza na zdolność do refleksji, przemyśleń zarówno nad życiem swoim, jak i narratora. Stąd też niezwykle istotny $w$ tej fazie staje się stosunek badacza do prowadzonych badań. Poszukiwanie odpowiedzi na pytania badawcze za wszelką cenę, nawet kosztem samopoczucia narratora, jego stanu emocjonalnego, może doprowadzić do zafałszowania wyników badań oraz niskiego poziomu wiarygodności badań. Ricouer (1989) jest zdania, iż narzucanie tekstowi narracyjnemu jednoznacznego brzmienia, skończonego rozumienia jest zabiegiem błędnym. Stąd też, jak twierdzi autor na wszystkich etapach interpretacji niezbędny jest dystans i odległość. Kolejna faza dotyczy analizy strukturalnej tekstu narracyjnego, w której podkreślam istotę łączenia różnych elementów tekstu w jedną zwartą całość. Ricouer nazywa ten moment paradygmatem akcji, podkreślając ważność zarówno głównych wątków tekstu z jego pobocznymi elementami wpisującymi się w całość opowiadanej historii życia. Miejsce teorii naukowych w rozumieniu tekstu narracyjnego to kolejny ważny etap. Odwołujemy się zatem do teorii naukowych pomocnych w rozumieniu poruszanych problemów. Wybór teorii do interpretacji podyktowany jest tematyką badawczą. W fazie rozumienia relacji: wiedza potoczna - wiedza naukowa, bierzemy pod uwagę obydwa typy wiedzy. W związku z tym, iż wiedza potoczna odzwierciedla sposób życia, poglądy narratorów, traktujemy oba obszary wiedzy jako równoprawnych partnerów na drodze poszukiwań badawczych. Potwierdzam zatem pogląd A. Schútza (1984, s. 177), który twierdzi, iż możemy dokonać interpretacji ludzkiej aktywności, jeśli w „ramach naturalnej postawy codziennego życia, potocznie, możemy zrozumieć w ogóle innych ludzi". Ostatnia faza zamyka rozumienie narracji. W tym miejscu, opierając się na kryteriach trafności badań jakościowych autorstwa J. Maxwella (Szkudlarek, 1997), dokonujemy podsumowania prowadzonych badań, jego analizy i interpretacji. Odwołujemy się zatem do kryterium trafności teoretycznej, kryterium trafności relacji wyjaśniania, kryterium trafności uogólnień i kryterium trafności relacji badawczej.

${ }^{25} \mathrm{H}$. Krúger, Wprowadzenie w teorie i metody badawcze nauk o wychowaniu, s. 140. 
wana. W taki oto sposób możemy być pewni, iż wydobycie na światło dzienne kontekstu procesów życiowych, wyrażonych w formie emocji, subiektywnych odczuć, odzwierciedli istotę spotkania.

Bogactwo tekstu zostaje ujawnione.

\section{Rozumienie narracyjne a refleksja fenomenologiczna}

Podstawową kategorią pojęciową w tej części rozważań staje się refleksja. Refleksja fenomenologiczna ujawnia bagaż przeżyć i doświadczeń, które stają się udziałem człowieka. Patrzymy zatem na historię życia z punktu widzenia doświadczenia osobistego, odzwierciedlonego przez uczucia, emocje, opis przeżyć. Co zatem czyni biografię wyjątkową? Co świadczy o jej szczególnym wyróżnieniu. W moim przekonaniu jest to refleksja, która wydobywa na światło dzienne znaczenie, jakie człowiek przypisuje temu co przeżył.

Aby w jakiś sposób zadośćuczynić powyższemu stwierdzeniu, odwołam się do dwóch znaczących myślicieli perspektywy fenomenologicznej. Są nimi Jean Lyotard i Edmund Husserl.

Jean Lyotard twierdzi,

dla fenomenologa to, co społeczne, nie jest w żaden sposób przedmiotem; jest czymś ujmowanym jako sfera przeżycia i chodzi tu (...) o adekwatny opis tego przeżycia, w celu odtworzenia jego sensu ${ }^{26}$.

Przyglądając się uważnie powyższemu stwierdzeniu, dla autora kategorią znaczącą jest odtwarzanie przeżycia w biografii człowieka oraz próba nadania mu sensu i znaczenia. Zdaniem autora, nie od razu rozumiemy jakie jest to znaczenie. Wymaga to czasu, refleksji, osobistego wglądu w świat przeżywany, integracji swojego wnętrza. Kontynuując dalej powyższy wątek, autor dodaje:

Nie przystępujemy nigdy do zjawiska związanego z człowiekiem, to znaczy do zachowania, nie kierując pod jego adresem pytania: co ono znaczy? (...) w naukach humanistycznych wyjaśnić naprawdę to umożliwić zrozumienie ${ }^{27}$.

Zrozumieć zatem człowieka, motywy jego działania, sposoby zachowania w różnych sytuacjach dnia codziennego, to próba zrozumienia siebie przez pryzmat różnych sytuacji, relacji z ludźmi. Takie podejście do kategorii rozumienia jest możliwe tylko wówczas, kiedy jak twierdzi autor, sam dla siebie nie jestem czystą przejrzystością. Proponuje zatem Lyotard, aby rozpoznając

\footnotetext{
${ }^{26}$ J-F. Lyotard, Fenomenologia, Warszawa 2000, s. 130.

${ }^{27}$ Tamże, s. 118.
} 
życie innego człowieka, zejść poniżej jego myślenia, odnaleźć płaszczyznę porozumienia, odkryć współistnienie mojego Ja i innego człowieka w świecie intersubiektywnym.

Czy można zatem nauczyć się rozumieć drugiego człowieka? Czy niezbędna jest do tego refleksja? A może potrzeba ustawicznego wglądu w siebie samego, rozpoznania swojego życie, a dopiero później spojrzenie na innego człowieka? Autor w swoich rozważaniach podkreśla znaczenie współistnienia $\mathrm{w}$ świecie społecznym. Być może wtedy moje spostrzeżenia, refleksje staną się punktem wyjścia poszukania odpowiedzi na powyższe pytania. Nakładamy zatem kategorię pojęciową rozumienia na zachowania, działania innego człowieka. Jest to możliwe dzięki przebywaniu w jednej sieci ludzkich zachowań. Wiem wtedy, że

rozumiem zachowania innego bądź mam rozumieć zachowania, na które nieuchronnie nakładam znaczenia. Dzieje się tak dlatego, że ten inny i ja sam byliśmy i pozostaniemy rozumiani w jednej sieci zachowań we wspólnym strumieniu wielu intencjalności ${ }^{28}$.

Refleksja fenomenologiczna otwiera nam zatem drogę do rozumienia istoty ludzkiego doświadczenia, w tym przede wszystkim rozumienia siebie. Aby nadać znaczenie temu co rozpoznajemy, co czynimy podstawą naszego społecznego funkcjonowania, trzeba wydobywać z siebie ustawiczną refleksyjność, przeświadczenie, że stajemy się częścią świata społecznego przy współudziale innych ludzi, uczestnicząc zarówno w świecie swoich indywidualnych przeżyć i doświadczeń, ale i innych ludzi, zapraszających nas do współbycia w świecie znaczeń.

Husserl mówi natomiast o działającym i doznającym Ja. Działający i doznający to osoba, która przybiera postać podmiotu odkrywającego swój wewnętrzny świat. To niewątpliwie podmiot wyznaczający sobie zadania, rozumiejący to, co wokół niego się dzieje, nadający sens i znaczenie temu wszystkiemu, co w biografii indywidualnej doświadcza. Dla Husserla Ja i świat otaczający są ze sobą nierozdzielnie związani. Wchodzimy zatem $\mathrm{w}$ relacje, wzajemne oddziaływanie ,jako podmioty $\mathrm{w}$ świecie podmiotów" ${ }^{29}$. Jesteśmy świadomi uczestnictwa w tym świecie. Należymy do tego świata, wyrażamy własnym głosem swoje myśli, spostrzeżenia, obiekcje. Cóż zatem przez Husserla znaczy rozumienie? Zdaniem autora, aby zrozumieć doświadczenia zarówno swoje, jak i drugiego człowieka musimy do niego podejść jako do osobowego podmiotu. Mówimy zatem o przebywaniu we

${ }^{28}$ Tamże, s. 126.

${ }^{29}$ E. Husserl, Idee czystej fenomenologii i fenomenologicznej filozofii, Księga II, Warszawa, 1974, s. 262. 
wspólnym świecie doświadczeń, wspólnych związkach osobowych, o integracji wewnętrznego Ja. Husserl twierdzi, iż

każde Ja może dla siebie samego i dla innych dopiero wtedy stać się osobą w normalnym sensie, osobą w związku osobowym, gdy zrozumienie wytworzy odniesienie do wspólnego świata otaczającego. Wspólny świat otaczający zyskuje wspólne momenty w nowym i wyższego stopnia sensie dzięki aktom wzajemnego określania, rozwijającym się na podłożu wzajemnego zrozumienia ${ }^{30}$.

Kategoria pojęciowa rozumienia zostaje rozszerzona o współbycie, współpracę, współprzebywanie dwóch podmiotów w świecie społecznym. Zdaniem Husserla, ludzie wywierają na siebie bezpośrednie osobowe oddziaływania, stają się one dla nich siłą motywującą do podejmowania wspólnych działań, ale i snucia refleksji o tym, co staje się ich udziałem. Stąd, szczególnego znaczenia nabiera w tym miejscu kategoria pojęciowa komunikacji. Zespala się ona z pojęciem rozumienia. Jeśli zatem rozumiem siebie, rozumiem drugiego człowieka, to wchodzimy razem ze sobą w proces komunikacji. Stajemy się dla siebie równoprawnymi podmiotami, które nie stoją naprzeciw sobie, lecz obok siebie. Podmioty te

żyją ze sobą, obcują, odnoszą się do siebie nawzajem aktualnie lub potencjalnie w aktach miłości, odwzajemnionej miłości, nienawiści i jej odwzajemniania, zaufania i wzajemnej ufności ${ }^{31}$.

Ta szczególna relacja pomiędzy moim Ja a innym człowiekiem nabiera dla Husserla szczególnego znaczenia. Dzieje się tak dlatego, iż w swoim świecie człowiek spotyka drugiego człowieka. Zaczyna go dostrzegać, rozumieć przez pryzmat własnego życia i doświadczeń osobistych. Zaczyna zatem rozumieć innych ludzi z tego powodu, iż dzięki przebywaniu w świecie komunikacji doświadcza zarówno siebie, jak i doświadcza drugiego człowieka, tworząc i kreując swój własny świat - świat tworzący się poprzez nić porozumienia.

Refleksja fenomenologiczna w ujęciu Husserla podkreśla znaczenia relacji z drugim człowiekiem, interpretacji zarówno swoich doświadczeń, jak i doświadczeń innych ludzi. Stajemy się zatem, w myśl Husserla, osobami czynnymi w swoim otaczającym świecie. Osobami, które wciąż na nowo podlegają determinowaniu.

W myśl powyższych założeń podkreślam istotę ludzkiej refleksji, prowadzącej, zdaniem Lyotarda ${ }^{32}$, do "możliwości rozumienia człowieka przez człowieka”, a zdaniem Husserla ${ }^{33}$ - do „osobowego, wzajemnego określania”.

\footnotetext{
${ }^{30}$ Tamże, s. 271.

${ }^{31}$ Tamże, s. 275.

${ }^{32}$ J-F. Lyotard, Fenomenologia, s. 121.

${ }^{33}$ E. Husserl, Idee czystej fenomenologii, s. 271.
} 


\section{Uwagi końcowe}

Zrozumieć narracyjnie siebie, ludzi i otaczający świat, to w moim odczuciu spojrzeć na wszystko co przeżywamy, odczuwamy z perspektywy doświadczających podmiotów. Nauka rozumienia dla wielu z nas może okazać się procesem długotrwałym, wpisanym w bieg życia. Dla innych może stać się okazją poznawania siebie, odkrywania wewnętrznego bogactwa istnienia, współbycia z innymi w świecie sensów i znaczeń. Dla jeszcze innych okazją przyjrzenia się temu co tworzymy, co nieustannie przekształcamy w toku naszej ludzkiej działalności. Rozmowa ze samym sobą, podjęcie dialogu z innymi w procesie ludzkiej komunikacji otwiera horyzont spotkania człowieka z człowiekiem w przestrzeni ludzkich doświadczeń. Wypowiedź wyrażona czy to ustnie, czy to $\mathrm{w}$ formie tekstu daje świadectwo ludzkiej umiejętności snucia opowieści o historii własnego życia. We własnym języku, z własnymi przekonaniami, wyobrażeniami i towarzyszącą temu spotkaniu refleksją bierzemy udział w teatrze ludzkiego życia.

Zaprezentowane w tekście przemyślenia dotyczące wpisania kategorii pojęciowej rozumienia narracyjnego $w$ perspektywę hermeneutyczno-fenomenologiczną oraz perspektywę interakcjonizmu interpretatywnego może stać się okazją do szerszego oglądu omawianych zjawisk również z punktu widzenia badacza, któremu dane jest doświadczać osobliwego spotkania z narratorem w trakcie procesu badawczego. Nabycie umiejętności badawczych jest zadaniem niezwykle trudnym. Niekoniecznie udaje się to z literaturą przedmiotu w ręku. Niezbędne stają się własne kompetencje badawcze, które uzyskujemy doświadczając zarówno spotkania z narratorem w trakcie badań, jak również podczas zgłębienia tajników interpretacji materiału empirycznego. Nastawienie na cierpliwe poszukiwanie danych, zgłębianie warsztatu badacza staje się punktem wyjścia do rozumienia istoty procesu badawczego, w którym uczestniczymy. Nastawienie na żmudne, czasochłonne badania, zdolność do refleksji, wydobywania cennych danych staje się niejako podróżą w (nie)znane.

(Z)rozumieć narracyjnie to spojrzeć na opowieść o życiu nie tylko z perspektywy badanej osoby. To próba uchwycenia również istoty rozumienia swojej historii życia. W myśl zasady: uczymy się siebie spoglądając na życie innych ludzi. Ta postawa staje się inspiracją zarówno dla badacza, jak i badanego, którzy otwierają przed sobą drzwi do rozumienia historii swojego życia. Przyjęta podczas badań forma narracyjna sprzyja rozumieniu tych obszarów życia, które do tej pory były poza zasięgiem interpretacyjnym obydwu podmiotów procesu badania.

W kontekście tych rozważań niezwykle interesująca wydaje mi się myśl Urszuli Tokarskiej na temat snucia opowieści o własnym życiu, którą przytaczam w obszerniejszym cytacie: 
Konstruując opowieść o własnym życiu, opowiadający wybiera zawsze określone wydarzenia (doświadczenia), które uznaje za istotne, znaczące, a które pozwalają lepiej zrozumieć - nie tylko odbiorcy, ale przede wszystkim jemu samemu - kim jest główny bohater opowieści, jakie są jego dążenia, obawy, możliwości działania oraz co go łączy z innymi postaciami tej historii, a co stanowi o jego odrębności. Ten, kto opowiada o własnym życiu jako o historii, której głównym bohaterem jest on sam, zostaje niejako „zmuszony" - zgodnie z regułami rozwijającej się narracji - do określenia takich aspektów funkcjonowania bohatera - a więc siebie samego - jak jego intencjonalność, świadomość celu, ku któremu zmierza oraz ewentualnych przeszkód na drodze jego realizacji, subiektywnie doświadczany stopień wpływu na przebieg własnej historii oraz przewidywane warianty zakończeń ${ }^{34}$.

Sądzę, iż powyższa wypowiedź wpisuje się w rozważanie na temat rozumienia tego, w czym jako podmioty uczestniczymy.

Te kilka uwag końcowych swoim zamiarem czyni zachętę młodych badaczy do swobodnego poruszania się po bogactwie perspektyw badawczych. Odkrycie istoty każdej z nich staje się okazją do chwili zadumy, refleksji, ale i ciekawości badawczej nastawionej na spotkanie z tym, co ciekawi, co interesuje, intryguje, co nieustannie zaprasza do rozumienia świata, w którym zarówno jako badacze, ale i zwykli ludzie funkcjonujemy.

\section{BIBLIOGRAFIA}

Ablewicz K., Hermeneutyczno-fenomenologiczna perspektywa badań w pedagogice, Wydawnictwo Uniwersytetu Jagiellońskiego, Kraków 1994.

Bauman T., Poznawczy status danych jakościowych, [w:] Metodologiczne problemy tworzenia wiedzy w pedagogice. Oblicza akademickiej praktyki, red. J. Piekarski, D. Urbaniak-Zając, K. Szmidta, Oficyna Wydawnicza Impuls, Kraków 2011.

Denzin N.K., Reinterpretacja metody biograficznej w socjologii: znaczenie a metoda $w$ analizie biograficznej, [w:] Metoda biograficzna w socjologii, red. J. Włodarek, M. Ziółkowski, Państwowe Wydawnictwo Naukowe, Warszawa 1990.

Husserl E., Idee czystej fenomenologii i fenomenologicznej filozofii, Księga II, Państwowe Wydawnictwo Naukowe, Warszawa 1974.

Grochalska M., Transgresyjne trajektorie. Zmiany statusu społecznego w perspektywie biograficznej, Oficyna Wydawnicza Impuls, Kraków 2011.

Griffin E., Podstawy komunikacji społecznej, Gdańskie Wydawnictwo Psychologiczne, Gdańsk 2002.

Lyotard J-F., Fenomenologia, Wydawnictwo KR, Warszawa 2000.

Kawecki I., Wiedza praktyczna nauczyciela, Oficyna Wydawnicza Impuls, Kraków 2004.

Krawczyk-Bocian A., Epistemologiczny poziom rozumienia tekstu narracyjnego, Przegląd Pedagogiczny, 2008, 1.

Krawczyk-Bocian A., Doświadczanie zdarzeń krytycznych. Narracje biograficzne dorostych dzieci alkoholików, Wydawnictwo Uniwersytetu Kazimierza Wielkiego, Bydgoszcz 2013.

${ }^{34}$ U. Tokarska, Narracja autobiograficzna w terapii i promocji zdrowia, [w:] Narracja jako rozumienie świata, red. J. Trzebiński, Gdańsk 2002, s. 238-239. 
Krawczyk-Bocian A., Biograficzne doświadczanie (nie)petnosprawności. W świetle teorii dezintegracji pozytywnej Kazimierza Dąbrowskiego" (w przygotowaniu).

Krüger H., Wprowadzenie w teorie i metody badawcze nauk o wychowaniu, Gdańskie Wydawnictwo Psychologiczne, Gdańsk 2005.

Nowak-Dziemianowicz M., Edukacja i wychowanie w dyskursie nauki i codzienności, Oficyna Wydawnicza Impuls, Kraków 2012.

Stemplewska-Żakowicz K., Zalewski B., Czym jest dobra narracja? Struktura narracji z perspektywy badaczy i klinicystów, [w:] Badania narracyjne w psychologii, red. M. Straś-Romanowska, B. Bartosz, M. Żurko, Wydawnictwo Eneteia, Warszawa 2010.

Pietrasiński Z., Syntezy wiedzy autobiograficznej podporzadkowane "roli" autokreacyjnej jednostki, [w:] O biografii i metodzie biograficznej, red. T. Rzepa, J. Leoński, Wydawnictwo Nakom, Poznań 1993.

Ricoeur P., Interpretacja a refleksja: Konflikt hermeneutyczny, Studia Filozoficzne, 1986, 9.

Ricoeur P., Jezzyk, tekst, interpretacja. Wybór pism, Państwowy Instytut Wydawniczy, Warszawa 1989.

Schutz A., Potoczna i naukowa interpretacja ludzkiego działania, [w:] Kryzys i schizma. Antyscjentystyczne tendencje w socjologii wspótczesnej, red. E. Mokrzycki, Państwowy Instytut Wydawniczy, Warszawa 1984.

Straś-Romanowska M., Na tropach psychologii jako nauki humanistycznej, Wydawnictwo Naukowe PWN, Warszawa - Wrocław 1995.

Szkudlarek T., Poststrukturalizm a metodologia pedagogiki, Socjologia Wychowania, 1997, 12.

Taylor Ch., Sources of the Self. The Making of the Modern Identity, Cambridge University Press, Cambridge 1989.

Trzebiński J., Narracja jako sposób rozumienia świata, Gdańskie Wydawnictwo Psychologiczne, Gdańsk 2002.

Tokarska U., Narracja autobiograficzna w terapii i promocji zdrowia, [w:] Narracja jako rozumienie świata, red. J. Trzebiński, Gdańskie Wydawnictwo Psychologiczne, Gdańsk 2002.

Walczak A., Czego można się nauczyć z biografii innych? Przykład Edith Piaf - istoty dramatycznej porwanej namiętnością, [w:] Biografie i uczenie się, red. E. Dubas, J. Stelmaszczyk, Wydawnictwo Uniwersytetu Łódzkiego, Łódź 2015. 